\title{
Distribution of bovine fasciolosis and associated factors in south Espírito Santo, Brazil: an update
}

\author{
Distribuição da fasciolose bovina e fatores associados no sul do Espírito Santo, Brasil: uma atualização
}

Isabella Vilhena Freire Martins ${ }^{1 *}$; Barbara Rauta de Avelar ${ }^{1}$; Cintia das Chagas Bernardo ${ }^{1}$; Alann Casotti de Leão ${ }^{1}$; Maria Julia Salim Pereira ${ }^{2}$

\author{
${ }^{1}$ Departamento de Medicina Veterinária, Centro de Ciências Agrárias, Universidade Federal do Espírito Santo - UFES, \\ Alegre, ES, Brasil \\ ${ }^{2}$ Departamento de Parasitologia Animal, Instituto de Veterinária, Universidade Federal Rural do Rio de Janeiro - UFRRJ, \\ Seropédica, RJ, Brasil
}

Received June 19, 2013

Accepted December 5, 2013

\begin{abstract}
The geographical distribution and factors associated with bovine fasciolosis in the south of Espírito Santo were updated and the prevalences of this disease and of snails of the genus Lymnaea in the municipality of Jerônimo Monteiro were calculated. In the first stage, fecal samples were collected from $10 \%$ of the herds of 115 farms in 23 municipalities and interviews were conducted with owners. Generalized linear mixed models were used. In the second stage, in Jerônimo Monteiro municipality, feces and mollusks were collected from all farms registered in the milk cooperatives in the region. The mollusks were identified and examined for infection by Fasciola hepatica. Fasciolosis was diagnosed in $18(78 \%)$ of the 23 municipalities. Of the 1157 fecal samples examined, $19.01 \%$ were positive for eggs of $F$. hepatica. The final model shows statistical evidence of associations between positive farms and previous cases of fasciolosis and concomitant grazing of cattle with other definitive hosts. In the evaluated farms from the studied municipality the prevalence of fasciolosis and Lymnaea was of $66.7 \%$ and $23.8 \%$, respectively. Mollusks were found in flooded areas and the animals' drinking water troughs. The wide geographical distribution of bovine fasciolosis in the south of Espírito Santo requires control measures to prevent its expansion towards the north of this state and other places characterized as $F$. hepatica free-infection.
\end{abstract}

Keywords: Fasciola hepatica, Lymnaea, epidemiology.

\section{Resumo}

Realizou-se um estudo atualizado da distribuição geográfica e dos fatores associados à fasciolose bovina, no Sul do Estado do Espírito Santo, e calculadas a prevalência de moluscos do gênero Lymnaea no município de Jerônimo Monteiro. Na primeira etapa, coletaram-se amostras fecais de 10\% dos rebanhos de 115 propriedades, em 23 municípios, e realizaram-se entrevistas com os proprietários. Modelos lineares generalizados mistos foram utilizados. Na segunda etapa, em Jerônimo Monteiro, coletaram-se fezes e moluscos em todas as propriedades cadastradas nas cooperativas de leite da região. Os moluscos foram identificados e examinados quanto à infecção por Fasciola hepatica. A fasciolose foi diagnosticada em 18 (78\%) dos 23 municípios. Das 1157 amostras fecais examinadas, 19,01\% foram positivas para ovos de $F$. hepatica. O modelo final mostra, concomitantemente, evidências estatísticas de associação entre propriedades positivas e casos anteriores de fasciolose e de pastoreio de bovinos com outros hospedeiros definitivos. Em Jerônimo Monteiro, a prevalência de fasciolose foi $66,7 \%$ e de Lymnaea $23,8 \%$. Moluscos foram encontrados em áreas alagadas e em bebedouros dos animais. A ampla distribuiçáo geográfica da fasciolose bovina, no Sul do Espírito Santo, requer medidas de controle que evitem sua expansão em direção ao Norte do Estado.

Palavras-chave: Fasciola hepática, Lymnaea, epidemiologia.

\footnotetext{
${ }^{*}$ Corresponding author: Isabella Vilhena Freire Martins

Departamento de Medicina Veterinária, Centro de Ciências Agrárias,

Universidade Federal do Espírito Santo - UFES, Alto Universitário, s/n,

CP 16, CEP 29500-000, Alegre, ES, Brasil

e-mail: isabella.martins@ufes.br
} 


\section{Introduction}

Fasciolosis is a disease caused by the trematode Fasciola hepatica, which can affect the liver of most mammals, but especially sheep and cattle. The disease is distributed throughout several regions of Brazil, being the states with the highest frequencies Rio Grande do Sul, Santa Catarina, Paraná, São Paulo, Minas Gerais, Rio de Janeiro, and Goiás (OLIVEIRA; SPÓSITO FILHA, 2009).

This disease may cause economic losses due to condemnation of affected livers (BERNARDO et al., 2011); mortality (ARAÚJO et al., 2007); decreased production of meat, milk and wool; reduced weight gain; and impaired fertility (DALTON, 1999). Moreover, fasciolosis is an important zoonosis for public health (ROBINSON; DALTON, 2009).

Fasciolosis is extensively distributed worldwide, and its range has been increasing over time because of transfers of parasitized animals from locations where the disease is enzootic to nonendemic areas (REID; DARGIE, 1995). In Brazil, parasitism by F. hepatica has been reported in the southern, southeastern and central-western regions (COSTA et al., 1986). However, the distribution within the endemic areas varies from extensive in the southern states to more focal in the southeastern and centralwestern states (LIMA et al., 2009).

Currently, fasciolosis is a significant economic problem for producers in the southern region of the state of Espírito Santo, where condemnation of bovine livers shows a historically increasing trend, with a mean prevalence of $22.91 \%$ over the period from 2006 to 2009 (BERNARDO et al., 2011). These authors' results led them to claim that fasciolosis had become established in the cattle herds of southern Espírito Santo. However, the slaughter data do not always allow identification of an animal's source. Later on, in a study carried out in ten municipalities in the south of the state of Espirito Santo, Alves et al. (2011) found cattle infected in all of them. These results confirmed that fasciolosis was autochthonous among cattle in this region. These authors also assessed the factors associated with infection by Fasciola in cattle, using bivariate analysis.

Since knowledge of parasite dispersion and the factors involved in maintenance of the parasitic cycle are important for choosing appropriate control measures, the aims of this study were (1) update the geographical distribution of fasciolosis and the factors associated with occurrences of fasciolosis in 23 municipalities of the southern region of the state of Espírito Santo, using multivariate analysis; and 2) assess the prevalence of bovine fasciolosis and of mollusks of the genus Lymnaea in the municipality of Jerônimo Monteiro.

\section{Materials and Methods}

In the first stage, between 2008 and 2010, data collected by Alves et al. (2011) in the following municipalities were used: Muqui, Mimoso do Sul, Cachoeiro de Itapemirim, Atílio Vivácqua, Castelo, Alegre, Jerônimo Monteiro, Guaçuí, Presidente Kennedy, and Muniz Freire. The municipalities of Itapemirim, Divino de São Lourenço, Marataízes, Vargem Alta, Apiacá, Rio Novo do Sul, Bom Jesus do Norte, São José dos Calçados, Ibitirama, Ibatiba, Iuna, Irupi, and Dores do Rio Preto were also included. These
23 municipalities compose the southern region of the state of Espírito Santo and are located between the UTM coordinates of 204217-309154 $\mathrm{m}$ and 7642859-7760032 $\mathrm{m}$ in the drainage basins of the Itapemirim, Itabapoana, and Benevente Rivers, which also cross the states of Rio de Janeiro and Minas Gerais.

To obtain the minimum number of farms needed to detect at least one farm with infected animals per municipality, the table in Thrusfield (1990) was used, taking the expected proportion of positive farms to be $50 \%$ and the number of farms per municipality to be $\geq 40$ (IBGE, 2006). A non-probabilistic sample of five farms per municipality was selected, thus totaling 115 farms. These farms were selected by the Institute of Agricultural and Forestry Protection (Instituto de Defesa Agropecuária e Florestal) of the state of Espírito Santo and by milk cooperatives in the region.

Fecal samples were collected from $10 \%$ of the lactating cows on each farm in the evaluated municipalities. The samples (about $10 \mathrm{~g}$ each) were collected directly from the rectum of each cow, being immediately labeled, stored refrigerated in an isothermal box and sent to the Parasitology Laboratory of the Agricultural Sciences Center, Federal University of Espírito Santo (Centro de Ciências Agrárias da Universidade Federal do Espírito Santo, CCA-UFES), where the sedimentation technique described by Foreyt (2005) was performed in order to detect F. hepatica eggs.

Between May 2008 and January 2010, each farm was visited to collect fecal samples and the farmer or the person in charge was interviewed to obtain data on the local environmental and herd management characteristics. These data included the presence of any flooded areas on the property, grazing areas shared with other definitive hosts (sheep, goats and horses), previous cases of fasciolosis, and occurrences of mollusk populations.

The global positioning system (GPS) was used for georeference the farms, being the coordinates obtained used to overlain on the map developed by Martins et al. (2012). The frequencies of the farms and animals positive for fasciolosis were calculated.

Bivariable and multivariable analyses were performed in order to study the relationship between fasciolosis on farms and the factors involved in their determination. Generalized linear mixed models (logistic regression with random effects) with a significance level of $5 \%$ were used because this model would lead to accounting for correlations (or clustering) between farms in the same municipalities (DOHOO et al. 2003). All variables included in the models were withdrawn one by one, according to the p-value, until the final model was obtained. To evaluate the quality of model fit, the Akaike Information Criterion (AIC) was used: in this, the model with the lowest AIC value shows the best fit.

Presence/absence of positive farms was considered to be the outcome variable, while areas covered by water bodies (presence/ absence), grazing areas shared with other definitive hosts (presence/ absence), previous cases of fasciolosis on the farm (presence/ absence) and mollusks in the flooded areas (presence/absence), as identified by the owner or person in charge of the farm, were taken to be the explanatory variables. The variable of municipality was used as a random effect.

Statistical analyses were performed using the R statistical package (R Development Core Team, 2009) and the lme4 package was used to adjust the models (BATES et al., 2010). 
In the second stage to study the prevalence of fasciolosis, due the highest frequency of fasciolosis in animals among the municipalities studied in the first stage, the municipality of Jerônimo Monteiro was chosen. All farms registered in the milk cooperatives of this region were visited between September 2010 and September 2011 (a total of 42 farms), and fecal samples were collected from all of the producing cows. The stool processing was performed as described above, using the technique described by Foreyt (2005). Mollusk samples were collected from the water courses, lagoons, ponds, drinking water tanks, and water plants, following the recommendations contained in Brasil (2008) using sieves of mesh size $0.5 \mathrm{~mm}$, over a 30 -minute period. The snails found were stored in bottles with water from the same collection site and were sent to the Parasitology Laboratory of CCA-UFES for identification based on morphological characteristics (PARAENSE, 1975, 1983, 1986).

The mollusks collected were exposed to direct artificial light for four hours and were then analyzed for the presence of larval forms of $F$. hepatica, in accordance with the Guide for Surveillance and Control of Mollusks of Epidemiological Importance (BRASIL, 2008).

\section{Results and Discussion}

In the first stage, out of the 23 municipalities, only Ibatiba, Irupi, Iuna, Ibitirama, and Divino São Lourenço did not showed animals infected by $F$. hepatica (Table 1 ), which may have been related to their location in the region of the Serra do Caparaó mountain range. This region has few lowland areas, which makes it unfavorable for the presence of flooded areas and thus for completion of the life cycle of $F$. hepatica. The municipalities of Iuna, Ibitirama, Dores do Rio Preto, and Divino de São Lourenço were considered to be low-risk areas for fasciolosis occurrence because the elevation of these municipalities exceeds $400 \mathrm{~m}$ and $80 \%$ of the areas of Dores do Rio Preto and Divino de São Lourenço lies above $800 \mathrm{~m}$ (MARTINS et al., 2012).

Most of the farms that were positive for fasciolosis were located in areas considered to be favorable or extremely favorable for development of fasciolosis, being the most of the negative farms located in areas considered to be less favorable or unfavorable (Figure 1), in accordance with the model developed by Martins et al. (2012). Hence, the present findings corroborates the results obtained through geoprocessing by those authors.

A total of 1,157 adult cattle were examined in the 23 municipalities of the southern region of the state of Espírito Santo. Of these, 220 were positive for F. hepatica by stool examinations, resulting in an infection percentage of $19.01 \%$ among the animals. Although the difference in relation to the number of positive animals on farms and the number of positive municipalities, the obtained results were similar that those found by Alves et al. (2011) in 10 municipalities in this region. In the present study, the figures were $44.34 \%$ (51/115) and $78.23 \%$ (18/23) respectively, which can be partly explained by sample sizes and the geomorphological characteristics and topography of the municipalities (MARTINS et al., 2012).
Table 1. Municipalities with at least one animal infected by Fasciola hepatica in the southern region of the Espírito Santo, in the period of 2008 to 2011.

\begin{tabular}{|c|c|c|c|}
\hline \multirow[t]{2}{*}{ Municipality } & \multirow{2}{*}{$\begin{array}{c}\text { Number } \\
\text { of animals } \\
\text { examined }\end{array}$} & \multicolumn{2}{|c|}{$\begin{array}{c}\text { Positives for Fasciola } \\
\text { bepatica }(\%)\end{array}$} \\
\hline & & Animals & $\begin{array}{c}\text { Farms } \\
(\mathrm{n}=5)\end{array}$ \\
\hline Alegre & 116 & 21.6 & 80 \\
\hline Apiacá & 22 & 13.6 & 40 \\
\hline Atilio Vivacqua & 21 & 28.9 & 80 \\
\hline Bom Jesus do Norte & 41 & 19.5 & 60 \\
\hline Cachoeiro de Itapemirim & 73 & 21.9 & 80 \\
\hline Castelo & 32 & 25 & 60 \\
\hline Divino de São Lorenço & 78 & 0 & 0 \\
\hline Dores do Rio Preto & 24 & 25 & 40 \\
\hline Guaçui & 31 & 12.9 & 60 \\
\hline Ibatiba & 43 & 0 & 0 \\
\hline Ibitirama & 19 & 0 & 0 \\
\hline Irupi & 23 & 0 & 0 \\
\hline Itapemirim & 41 & 20 & 20 \\
\hline Iuna & 32 & 0 & 0 \\
\hline Jerônimo Monteiro & 79 & 55.7 & 80 \\
\hline Marataizes & 40 & 12.5 & 40 \\
\hline Mimoso do sul & 50 & 12 & 40 \\
\hline Muniz Freire & 120 & 7.5 & 20 \\
\hline Muqui & 47 & 48.9 & 100 \\
\hline Presidente Kennedy & 48 & 27.1 & 60 \\
\hline Rio Novo do Sul & 21 & 9.5 & 20 \\
\hline São José do Calçado & 36 & 8.3 & 40 \\
\hline Vargem Alta & 20 & 45 & 60 \\
\hline
\end{tabular}

Other studies that examined animal stool samples for diagnosis of $F$. hepatica infection, found similar proportions. For example, the study developed by Gomes et al. (2002) in the municipality of Campos dos Goytacazes in the state of Rio de Janeiro found that $15.83 \%$ of the cattle were positive for the parasite. In a study on 120 municipalities in the state of Minas Gerais, Lima et al. (2009) found that 16 municipalities (13\%) presented infected animals and, in these localities, $23.61 \%$ of the animals were infected, which was an infection proportion similar to that reported here. These authors claimed that the southern and southwestern regions of Minas Gerais have favorable ecoepidemiological conditions for occurrences of $F$. hepatica. Thus, the spread of fasciolosis to the southern region of the state of Espírito Santo may be attributed to its proximity to the municipality of Campos dos Goytacazes and to the state of Minas Gerais, which have infected animals. This proximity favors dispersion of mollusks infected with $F$. hepatica through water bodies and introduction of infected animals through the considerable volume of animal traffic, thus creating suitable conditions for autochthonous occurrence of fasciolosis in this region.

Serra-Freire and Nuernberg (1992) reported that there was high prevalence $(27.83 \%)$ in the state of Santa Catarina, after examination of fecal samples from 7,156 cattle in 129 municipalities. In a few municipalities of the state of Espírito Santo, including Castelo, 


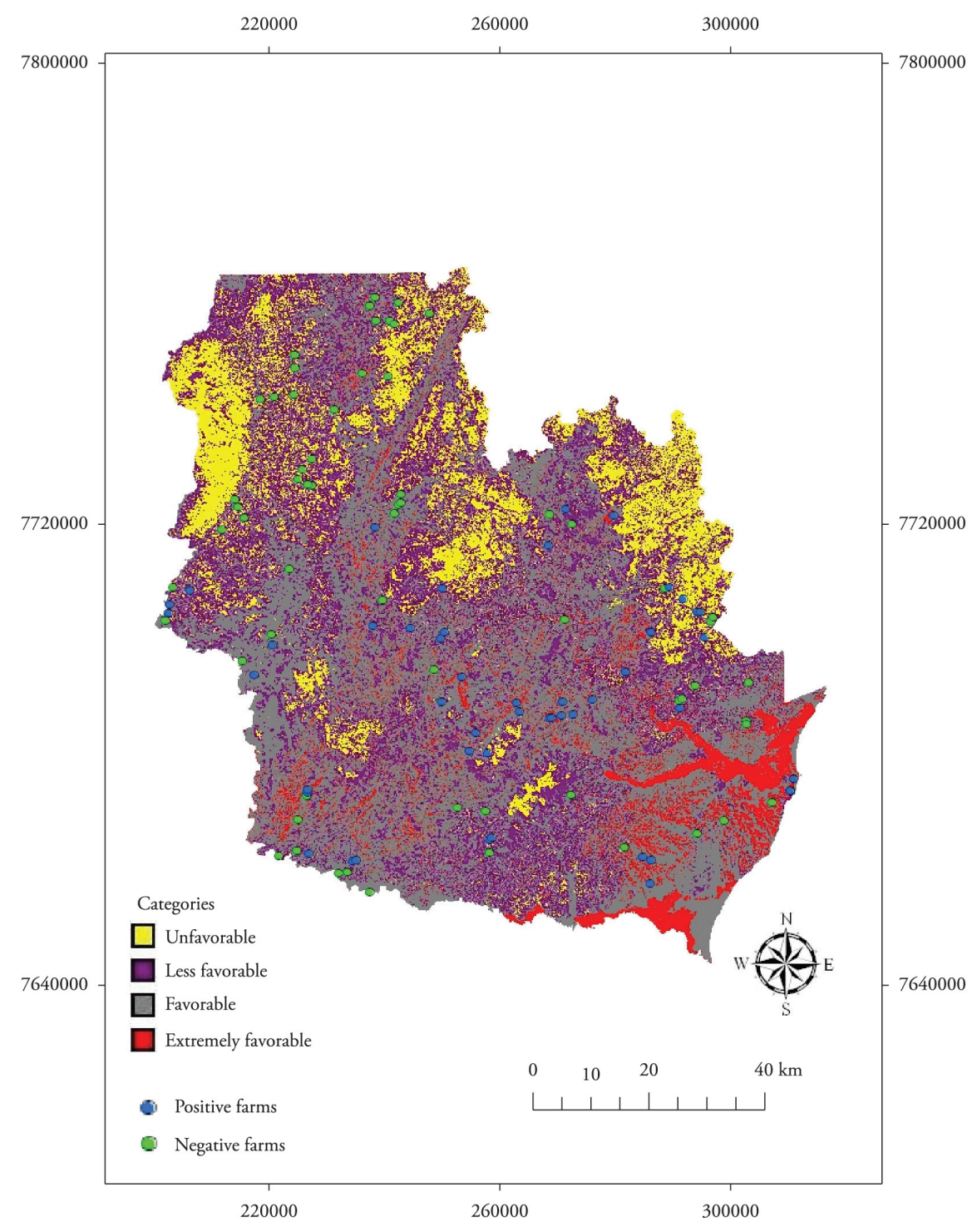

Figure 1. Georeferenced farms showing the distribution of bovine fascioliasis in the southern region of Espírito Santo State in 2008 to 2011 and overlaid on the classifying map for the degrees of favorability for fascioliasis developed by Martins et al. (2012) with geoprocessing techniques.

Presidente Kennedy, Dores do Rio Preto, and Atílio Vivaqua, the percentages were similar to those reported from the municipalities of Santa Catarina, an area traditionally considered endemic for fasciolosis. Nevertheless, municipalities such as Jerônimo Monteiro (55.7\%), Muqui (48.9\%), and Vargem Alta (45\%) exhibited unusually high percentages.

However, Queiroz et al. (2002) reported an infection percentage of only $8 \%$ among cattle in herds sampled in the municipalities of Bocaiúva do Sul and Tunas do Paraná, which may have occurred because the authors used the Hoffman, Pons and Janer methodology, which is a sedimentation technique for identification of Schistosoma mansoni eggs (HOFFMAN et al., 1934).

Presence of areas with water bodies, reports of mollusks, grazing in areas shared with other hosts and previous cases of bovine fasciolosis on the farms, which were diagnosed by viewing parasites in the liver after slaughtering, were reported by 83, 49, 75 and $17 \%$ of the interviewees, respectively (Table 2 ).
The data from the association analysis are shown in Tables 2 and 3. A significant association between areas with water bodies and positive farms was observed (Table 2) and this corroborates the results reported by Alves et al. (2011) in some municipalities of this region and by Oliveira (2008), who also observed an association between bovine fasciolosis and the presence of flooded areas on farms in the municipalities of Itajubá and Careaçu in the state of Minas Gerais, where $89 \%$ of the positive farms had flooded areas. This association is considered relevant because flooded areas are essential for the survival of the intermediate host, and thus, this association is considered to be a risk factor for the spread of fasciolosis. Although not statistically significant, this variable remained in the final model (Table 3) because of its plausibility and because it improved the fit of the model.

On the other hand, it should be noted that these authors observed that mollusks were present in tanks of drinking water for the animals, in locations where there were no flooded areas, 
Table 2. Bivariate analysis of factors associated with infection by Fasciola hepatica in cattle from farms of the southern region of Espírito Santo State from 2008 to 2011 .

\begin{tabular}{|c|c|c|c|c|}
\hline \multirow[t]{2}{*}{ Factor } & \multirow[t]{2}{*}{ Category } & \multicolumn{2}{|c|}{ Farms $(n=115)$} & \multirow[t]{2}{*}{$P$-value } \\
\hline & & Positive (\%) & Negative & \\
\hline \multirow[t]{2}{*}{ Areas with water bodies } & presence & $48(50.0)$ & 48 & 0.00954 \\
\hline & absence & $03(15.8)$ & 16 & \\
\hline \multirow[t]{2}{*}{ Report of mollusks } & presence & $37(64.9)$ & 20 & 0.00009 \\
\hline & absence & $14(24.1)$ & 44 & \\
\hline \multirow[t]{2}{*}{ Report of previous cases } & presence & $18(90.0)$ & 02 & 0.00098 \\
\hline & absence & $33(34.7)$ & 62 & \\
\hline \multirow[t]{2}{*}{ Grazing in areas shared with other hosts } & presence & $49(56,3)$ & 38 & 0.00045 \\
\hline & absence & $02(7.1))$ & 26 & \\
\hline
\end{tabular}

Table 3. Final model of the factors associated with infection by Fasciola hepatica in cattle from farms of the southern region of Espírito Santo State from 2008 to 2011.

\begin{tabular}{lcc}
\hline \multicolumn{1}{c}{ Factor } & $\begin{array}{c}\text { Coeficiente de } \\
\text { Regressáo }\left(\beta_{\mathrm{i}}\right)\end{array}$ & $\boldsymbol{P}$-value \\
\hline Areas with water bodies & 1.4062 & 0.1393 \\
Report of previous cases & 2.5801 & 0.0053 \\
Grazing in areas shared & 2.8340 & 0.0036 \\
with other hosts & & \\
\hline
\end{tabular}

thus enhancing the possibility of source infection on some farms, since larvae may be present in substrates in this water.

The farms where mollusks were reported showed twice as high a proportion of animals with fasciolosis as on farms with no reported mollusks (Table 2), but surprisingly, this variable did not remain in the final model. Lymnaea columella was previously identified morphologically and molecularly by Almeida (2010) in 13 of the 23 municipalities of the present study. This author attributed the dispersal of mollusks in these municipalities to high rainfall, which leads to frequent flooding during the summer. During these rainy periods, the mollusks were found on the vegetation and attached to the slopes of low-flow flooded areas. Although the reports of mollusks in the municipalities came from the farmers at this stage of the present study, these data indicate the geographical dispersion of Lymnaea within the region.

In all of the 18 municipalities where infected animals were diagnosed, the presence of mollusks was reported, thus reinforcing the importance of mollusks, whose presence must precede infection. Moreover, these results indicate the consistency of responses among the farmers. On the other hand, Lima et al. (2009) detected mollusks in 13 of the 16 municipalities (81.2\%) with parasitized cattle.

At the farm level, presence of mollusks was reported by the farmers in $72.5 \%$ (37/51) of the farms with infected animals. Although Alves et al. (2011) reported that Lymnaea snails were present on farms with positive animals, no statistical association was found. These authors attributed this to their great difficulty in finding the mollusks because of their adhesion to vegetation or mud. Likewise, one limitation of the present study was the farm owners' difficulty in identifying the presence of mollusks because, depending on the time of year, the mollusks may be buried (during periods of drought) or submerged (periods of heavy rains). However, despite this difficulty in the present study, reports of mollusks at municipality level coincided with $100 \%$ of the municipalities with infected animals.

The farms with previous reports of fasciolosis had twice as high a proportion of current infection as among those with no prior reports. It should be noted that the owners made it clear in the interviews that these previous cases in their animals always involved viewing of Fasciola specimens in the liver, either at the slaughterhouse or on their own farm. On 20 farms in the present study that reported previous fasciolosis cases, the farmers had not used any medication to treat this disease, and this is a factor that contributes towards maintaining and spreading the infection in the region. In the study by Alves et al. (2011), no association was found between positive rural farms and previous cases of fasciolosis, perhaps due to the sample size.

There was a significant association between the proportion of positive farms and the presence of other definitive hosts (horses, sheep or goats) grazing the same area (Tables 2 and 3). Farms with other definitive hosts had a sevenfold higher proportion of animals positive for fasciolosis than farms without other hosts. This result corroborates the findings of Alves et al. (2011), who found an association between these variables in their study on 10 municipalities in this region. Furthermore, in the same municipalities, Carneiro (2010) reported the presence of $F$. hepatica infecting sheep, goats, and buffaloes in nine of these municipalities. In Pakistan, the importance of the role of other definitive hosts in spreading fasciolosis was reported by Khan et al. (2009) that affirmed an association between the presence of small ruminants eliminating feces onto the same pasture and increased prevalence of fasciolosis in cattle on these farms.

It is important to know about the factors responsible for susceptibility to and successful maintenance of infection in definite hosts and the role of these factors in disease transmission in different regions. The most important definitive host for this parasite is sheep, and it has been estimated that a single sheep can contaminate the field daily with over half a million eggs from only a mild subclinical infection, and with 2.5 to 3 million eggs per day in cases of moderate infection (BORAY, 1969).

In the second stage of the present study, the prevalence of fasciolosis in the municipality of Jerônimo Monteiro on dairy cattle farms registered in the milk cooperatives was $66.7 \%(28 / 42)$. The prevalence of mollusks of the genus Lymnaea on these farms 
was $23.8 \%$ (10/42); however, immature forms of $F$. hepatica were not found in any of the specimens. In addition to Lymnaea sp., specimens of Biomphalaria sp. and Physa sp. were also found. It should be noted that no mollusk species were found on 32 farms, while on four farms, mollusks were found not only in flooded areas such as dams, ponds and small streams, but also in drinking troughs, thus corroborating the findings of Oliveira (2008) and Lima et al. (2009) in the Sapucaí River basin in the state of Minas Gerais. This finding may be epidemiologically relevant and should be investigated because on farms that lack flooded areas, infected mollusks may reach the animals' drinking water reservoirs, thus allowing the metacercariae to encyst in substrates present in the reservoirs. In the Patagonia region of Argentina, Kleiman et al. (2007) reported high prevalence of infected animals (52\%) and infected L. viatrix, which ranged from 0.9 to $14 \%$, depending on the sampling site and the season, with no infected mollusks detected in the spring. In the valley of the Paraíba River, infected L. columella was found in every month except December during a three-year study (AMATO et al., 1986). In the present study, the fact that no infected mollusks were found on the farms with infected cattle may be explained by the low rate of natural infection (2.96\%) reported by Lima et al. (2009), who found infected mollusks in only one of the 16 municipalities with infected cattle. These authors attributed their failure to recover immature forms of $F$. hepatica from mollusk tissues to the sampling site; moreover, the single sample recovered was obtained without taking into consideration mollusk seasonality, which may also have occurred in the present study.

Given that the municipalities included in the present study are located in the drainage basins of the Itapemirim, Itabapoana, and Benevente Rivers, which also cross the states of Rio de Janeiro and Minas Gerais, it is likely that in addition to the animal traffic in the border regions, these basins have contributed towards the spread of fasciolosis to the state of Espírito Santo from the already infected states of Rio de Janeiro and Minas Gerais.

The results indicate that factors associated with animal management are important risk factors for fasciolosis in this region. Animal transit between farms, a factor that was reported by the producers during the interviews, may also have contributed to the spread of fasciolosis. Thus, preventive measures should take into consideration limiting animal grazing in areas susceptible to periodic flooding, avoiding the grazing of animals of different species in the same area and monitoring animals through fecal examination and deworming.

\section{Acknowledgments}

This research was supported by CAPES (Coordination for the Improvement of Higher Education Personnel) - PROCAD no093/2007.

\section{References}

Alves DP, Carneiro MB, Martins IVF, Bernardo CC, Donatele DM, Pereira OS Jr, et al. Distribution and factors associated with Fasciola hepatica infection in cattle in the south of Espírito Santo State, Brazil.
J Venom Anim Toxins incl Trop Dis 2011; 17(3): 271-276. http://dx.doi. org/10.1590/S1678-91992011000300006

Amato SB, De Rezende HEB, Gomes DR, Freire NMS. Epidemiology of Fasciola hepatica infection in the Paraíba Valley, São Paulo. Vet Parasitol 1986; 22(3-4): 275-284. http://dx.doi.org/10.1016/03044017(86)90115-9

Almeida BR. Malacologia dos gêneros Lymnaea e Biomphalaria na mesorregião sul espirito-santense, e a avaliação de extratos de Melia azedarach, Azadirachta indica, e Cymbopogon winterianus como agentes moluscicidas [Dissertaçâo]. Alegre: Universidade Federal do Espírito Santo; 2010.

Araújo JLB, Linhares GFC, Oliveira APM, Amoril JG, Freitas MR, Costa IC, et al. Infecçóes autóctones de bovinos por Fasciola hepatica Linnaeus, 1758 (Trematoda, Fasciolidae) no Estado de Goiás, Brasil. Rev Patol Trop 2007; 36(1): 96-100.

Bates D, Maechler M, Bolker B, Walker S. lme4: Linear mixedeffects models using Eigen and S4. R package version 0.999375-35. [online] 2010 [cited 2013 Jan 5]. Available from: http://CRAN.Rproject.org/package $=1$ me 4 .

Bernardo CC, Carneiro MB, Avelar BR, Donatele DM, Martins IVF, Pereira MJS. Prevalence of liver condemnation due to bovine fasciolosis in southern Espírito Santo: temporal distribution and economic losses. Rev Bras Parasitol Vet 2011; 20(1): 49-53. http://dx.doi.org/10.1590/ S1984-29612011000100010

Boray JC. Experimental fascioliasis in Australia. Adv Parasitol 1969; 7: $95-$ 210. http://dx.doi.org/10.1016/S0065-308X(08)60435-2

Brasil. Ministério da saúde. Vigilância e controle de moluscos de importância epidemiológica, Brasilia, Brasil [online]. 2008 [cited 2009 May 5]. Available from: http://bvsms.saude.gov.br/bvs/publicacoes/vigilancia_ controle_moluscos_import_epidemio_2ed.pdf.

Carneiro MB. Estudo epidemiológico da Fasciola hepatica em ovinos, caprinos e bubalinos em municipios da região sul do Espírito Santo [Dissertação]. Alegre: Universidade Federal do Espírito Santo; 2010.

Costa HMA, Leite ACR, Guimarães MP, Lima WL. Distribuição de helmintos parasitos de animais domésticos no Brasil. Arq Bras Med Vet Zoot, 1986; 38(4): 465-579.

Dalton JP. Epidemiology and control. In: Fascioliasis. Cambridge: CAB International, University; 1999. p. 113-149.

Dohoo I, Martin W, Stryhn H. Veterinary Epidemiologic Research. Charlottetown: AVC; 2003.

Foreyt WJ. Parasitologia Veterinária: manual de referência. 5. ed. São Paulo: Roca. 2005.

Gomes FF, Oliveira FCR, Pile EA, Lopes CWG. Estabelecimento de foco de fasciolose hepática em propriedade do município de Campos dos Goytacazes no estado do Rio de Janeiro, Brasil. Rev Bras Parasitol Vet 2002; 11(2): 53-56.

Hoffman WA, Pons JA, Janer SL. The sedimentation-concentration method in Schistosomiasis mansoni. Puerto Rico J Public Health. 1934; 9: 283-291.

Instituto Brasileiro de Geografia e Estatística - IBGE. Censo Agropecuário [online]. 2006. [cited 2008 Oct 5]. Available from: http://www.ibge. gov.br/cidadesat/comparamun/compara.php? $\operatorname{coduf}=32$ \&idtema $=3 \& \mathrm{c}$ $\mathrm{odv}=\mathrm{v} 100$.

Khan MK, Sajid MS, Khan MN, Iqbal Z, Iqbal MU. Bovine fasciolosis: Prevalence, effects of treatment on productivity and cost benefit analysis in five districts of Punjab, Pakistan. Res Vet Sci 2009; 87(1): 70-75. http:// dx.doi.org/10.1016/j.rvsc.2008.12.013 
Kleiman F, Pietrokovsky S, Prepelitchi L, Carbajo, AE, Wisnivesky-Colli C. Dynamics of Fasciola hepatica transmission in the Andean Patagonian valleys, Argentina.Vet Parasitol 2007; 145(3-4): 274-286. http://dx.doi. org/10.1016/j.vetpar.2006.12.020

Lima WS, Soares LRM, Barçante TA, Guimaraes MP, Barçante JMP. Occurrence of Fasciola hepatica (Linnaeus, 1758) infection in Brazilian cattle of Minas Gerais, Brazil. Rev Bras Parasitol Vet 2009; 18(2): 27-30. http://dx.doi.org/10.4322/rbpv.01802006

Martins IVF, Avelar BR, Pereira MJS, Fonseca AH. Application of a geographical information system approach for risk analysis of fascioliasis in southern Espírito Santo State, Brazil. Geospat Health 2012; 6(3): S87-S93.

Oliveira EL. Prevalência e fatores associados à distribuição da Fasciola hepatica (Linnaeus, 1758) em bovinos dos municípios de Careaçú e Itajubá, regiāo da bacia do rio Sapucaí-Minas Gerais [Dissertação]. Belo Horizonte: Universidade Federal de Minas Gerais; 2008.

Oliveira SM, Spósito Filha E. Fasciolose hepática. Biológico 2009; 71(1):5-7.

Paraense WL. Estado atual da sistemática dos planorbídeos brasileiros. Arq Mus Nac Rio de Janeiro. 1975; 55: 105-128.

Paraense WL. Lymnaea columella in Northern Brazil. Mem Inst Oswaldo Cruz 1983; 78(4): 477-482. http://dx.doi.org/10.1590/S007402761983000400011
Paraense WL. Physa marmorata Guilding, 1828 (Pulmonata: Physidae). Mem Inst Oswaldo Cruz 1986; 81(4): 459-469. http://dx.doi. org/10.1590/S0074-02761986000400014

Queiroz VS, Luz E, Leite LC, Círio SM. Fasciola hepatica (Trematoda, Fasciolidae): estudo epidemiológico nos municípios de Bocaiúva do Sul e Tunas do Paraná (Brasil). Acta Biol Par 2002; 31(1-4): 99-111.

$\mathrm{R}$ Development Core Team. $R$ : A language and environment for statistical computing [online]. Vienna: R Foundation for Statistical Computing; 2009 [cited 2010 Jan 5]. Available from: http://www.Rproject.org.

Reid JFS, Dargie JD. Como os estágios adultos da Fasciola hepatica afetam a saúde e a produtividade do bovino. Hora Vet 1995; ediçáo extra (1): 23-26.

Robinson MW, Dalton JP. Zoonotic helminth infections with particular emphasis on fasciolosis and other trematodiases. Philos Trans $R$ Soc Lond B Biol Sci 2009; 364(1530): 2763-2776. http://dx.doi.org/10.1098/ rstb.2009.0067

Serra-Freire NM, Nuernberg S. Geopolitical dispersion of the occurrence of Fasciola hepatica in the state of Santa Catarina, Brazil. Mem Inst Oswaldo Cruz 1992; 87(S1): 263-269. http://dx.doi.org/10.1590/ S0074-02761992000500050

Thrusfield M. Epidemiología Veterinaria. Zaragoza: Acribia; 1990. 